\title{
HUBUNGAN PENGETAHUAN DAN PERILAKU IBU TENTANG KELUARGA SADAR GIZI (KADARZI) DENGAN STATUS GIZI ANAK BALITA DI POSYANDU TERATAI, DUSUN SANANSARI, SRIMARTANI, PIYUNGAN, BANTUL, D.I. YOGYAKARTA TAHUN 2018
}

\author{
Maylan Emilyani Dias Simon ${ }^{1}$, Sarni Anggoro ${ }^{2}$ \\ ${ }^{1}$ Kesehatan Masyarakat, Stikes Surya Global Yoyakarta \\ email: Maylan Emilyani Dias Simon_1@maylandias2@gmail.com \\ ${ }^{2}$ Kesehatan Masyarakat, Stikes Surya Global Yogyakarta \\ email: Sarni Anggoro_2@sarnianggoro73@gmail.com
}

\begin{abstract}
Background: Malnutrition is one of the causes of morbidity and mortality in children under five years of age. Toddlers need nutrients in large quantities because of the rapid growth process. In 2017 there are 14\% of children under five experiencing underweight. The national prevalence of nutritional problems among children under five in 2017 in the stunting category was $29.6 \%$ and underweight was $17.8 \%$ (Riskesdas, 2018). The malnourished sufferers of Piyungan Community Health Center work area are 3.8\% and in Srimartani village there are $11.39 \%$ malnourished children under five. In addition, in the Sanansari Hamlet Posyandu in September there were 5.4\% of children under five with underweight and stunting conditions. Research Objective: To find out the relationship between Knowledge and Behavior of Mother About Nutrition Conscious Family with Nutritional Status of Toddlers in Teratai Posyandu in Sanansari Village, Srimartani Village, Piyungan District, Bantul, D. I. Yogyakarta in 2018. Research Method: This research is a descriptive analytic research with cross sectional approach. The samples in this study were all toddlers in the Teratai Posyandu, which numbered 74 toddlers. The sampling technique is done by the Total Sampling technique. The statistical test used is to use Chi Square (x2). Results: Knowledge about Nutrition Conscious Family was partially in the good category (63.5\%), the mother's behavior about Nutrition Conscious Family was partly in good category (90.5\%), then there was a relationship between mother's knowledge and behavior about Nutrition Conscious Family at the Teratai Posyandu, Sanansari, Srimartani, Piyungan, Bantul is characterized by a significant value of 0.050 and 0.00 , respectively $(P<0.05)$. Conclusion: There is a significant relationship between mother's knowledge and behavior about Nutrition Conscious Family and the nutritional status of children under five in Teratai Posyandu, Sanansari Hamlet, Srimartani, Piyungan, Bantul, Year 2018.
\end{abstract}

Keywords: Knowledge, Behavior, Nutritional Status

\section{PENDAHULUAN}

Kekurangan gizi menjadi salah satu penyebab kesakitan dan kematian pada anak-anak usia dibawah lima tahun. Balita membutuhkan zat-zat gizi dalam jumlah yang besar karena terjadi proses tumbuh kembang yang sangat pesat. Badan Kesehatan Dunia (WHO, 2017) menyatakan bahwa di negara berkembang pada tahun 2017 terdapat $14 \%$ anak balita mengalami underweight. Prevalensi nasional masalah gizi pada balita pada tahun 2017 adalah balita dalam kategori stunting $29,6 \%$ dan balita dalam kategori underweight atau balita dengan status gizi buruk atau gizi kurang 17,8\%. Provinsi Daerah Istimewa Yogyakarta (DIY) prevalensi balita gizi buruk atau gizi kurang $12,6 \%$, balita dengan status pendek (stunting) 19,8\%, dan balita dengan status sangat kurus dan kurus (wasting) 8,3\%. Sedangkan, prevalensi balita gizi buruk di Kabupaten Bantul 


\section{Jurnal Delima Harapan 2020}

pada tahun 2017 sebanyak 15,2\%. Menurut data yang didapat dari Dinas Kesehatan Kota Bantul dapat diketahui bahwa data dengan status gizi terendah yaitu berada di wilayah kerja Puskesmas Piyungan yaitu sebanyak 3,8\%. (Riskesdas, 2018).

Kadarzi adalah program yang dijalankan pemerintah dengan harapan keluarga mampu mengenal, mencegah dan mengatasi masalah gizi setiap anggotanya. Keluarga disebut Kadarzi apabila telah berperilaku gizi yang baik yang dicirikan minimal dengan menimbang berat badan secara teratur, memberikan ASI eksklusif, makan beranekaragam, menggunakan garam beryodium, minum suplemen gizi sesuai anjuran. Kadarzi diwujudkan dengan cara meningkatkan pengetahuan gizi dan perilaku gizi keluarga yang kurang mendukung serta menumbuhkan kemandirian keluarga untuk mengatasi masalah gizi yang ada dalam keluarga. Rendahnya pengetahuan dan perilaku masyarakat khususnya ibu-ibu rumah tangga terhadap gizi dan kesehatan merupakan faktor yang berpengaruh pada pencapaian program Kadarzi (Dinkes DIY, 2017).

Posyandu Teratai merupakan salah satu Posyandu yang berada di Desa Srimartani dan berada dalam wilayah kerja Puskesmas Piyungan. Menurut data yang diperoleh dari Puskesmas bahwa di Desa Srimartani terdapat $11,39 \%$ balita gizi kurang. Selain itu, data yang diperoleh dari Posyandu Teratai Dusun Sanansari bulan September terdapat $5,4 \%$ balita dengan kondisi kurus dan stunting.

Berdasarkan latar belakang tersebut perlu dilakukan penelitian mengenai adakah Hubungan Pengetahuan dan Perilaku Ibu Tentang Kadarzi (Keluarga Sadar Gizi) Dengan Status Gizi Anak Balita di Posyandu Teratai Dusun Sanansari, Srimartani, Piyungan, Bantul, D.I.Yogyakarta Tahun 2018 ?

Tujuan umum dari penelitian ini adalah untuk Mengetahui Hubungan Pengetahuan dan Perilaku Ibu Tentang Kadarzi (Keluarga Sadar Gizi) dengan
Status Gizi Anak Balita di Posyandu Teratai Dusun Sanansari, Desa Srimartani, Kecamatan Piyungan, Bantul, D.I.Yogyakarta Tahun 2018.

\section{METODE PENELITIAN}

Pada penelitian ini menggunakan desain penelitian deskriptif kuantitatif. Survey diskriptif. Pendekatan penelitian ini adalah menggunakan Cross Sectional, merupakan penelitian deskriptif dimana subjek penelitian ini dilakukan dengan mengidentifikasi melalui pemberian kuesioner pada ibuibu yang memiliki anak balita yang berada dalam wilayah kerja Puskesmas Piyungan, berpusat pada wilayah Posyandu Teratai Dusun Sanansari.

\section{POPULASI DAN SAMPEL}

Populasi penelitian ini melihat pada cakupan status gizi yang ada di Posyandu Teratai Dusun Sanansari Kecamatan Piyungan. Maka jumlah populasi pada penelitian ini adalah seluruh ibu yang memiliki balita (0-59 bulan) di posyandu Teratai Dusun Sanansari dengan total keseluruhan 74 balita.

Pengambilan sampel ditentukan berdasarkan Nonprobability Sampling dengan metode Total sampling .

Dalam proses pengolahan data terdapat langkah-langkah yang harus ditempuh:

\section{Editing \\ 2. Coding \\ 3. Entry \\ 4. Tabulating}

Untuk analisa data yaitu dengan analisis univariat digunakan untuk mengetahui gambaran umum data mengenai karakteristik responden meliputi umur, pendidikan, pekerjaan ibu. Serta menggambarkan distribusi frekwensi pengetahuan dan, perilaku tentang keluarga sadar gizi yang disajikan dalam bentuk tabel distribusi frekuensi.

Untuk Analisis Bivariat, yaitu data yang terkumpul dianalisa dengan menggunakan teknik analisis korelasi. Untuk melihat hubungan antara pengetahuan ibu tentang keluarga sadar gizi dengan status gizi anak balita dan hub ungan perilaku ibu tentang keluarga 


\section{Jurnal Delima Harapan 2020}

sadar gizi dengan status gizi anak balita. Sedangkan Uji statistik yang digunakan adalah uji Chi Square.

\section{HASIL PENELITIAN DAN PEMBAHASAN:}

Berikut ini merupakan distribusi umur ibu balita di Posyandu Teratai, Dusun Sanansari, Srimartani, Piyungan, Bantul pada bulan Oktober tahun 2018:

Tabel 1. Distribusi Frekuensi Umur Responden di Posyandu Teratai, Dusun Sanansari, Srimartani, Piyungan, Bantul, Tahun 2018.

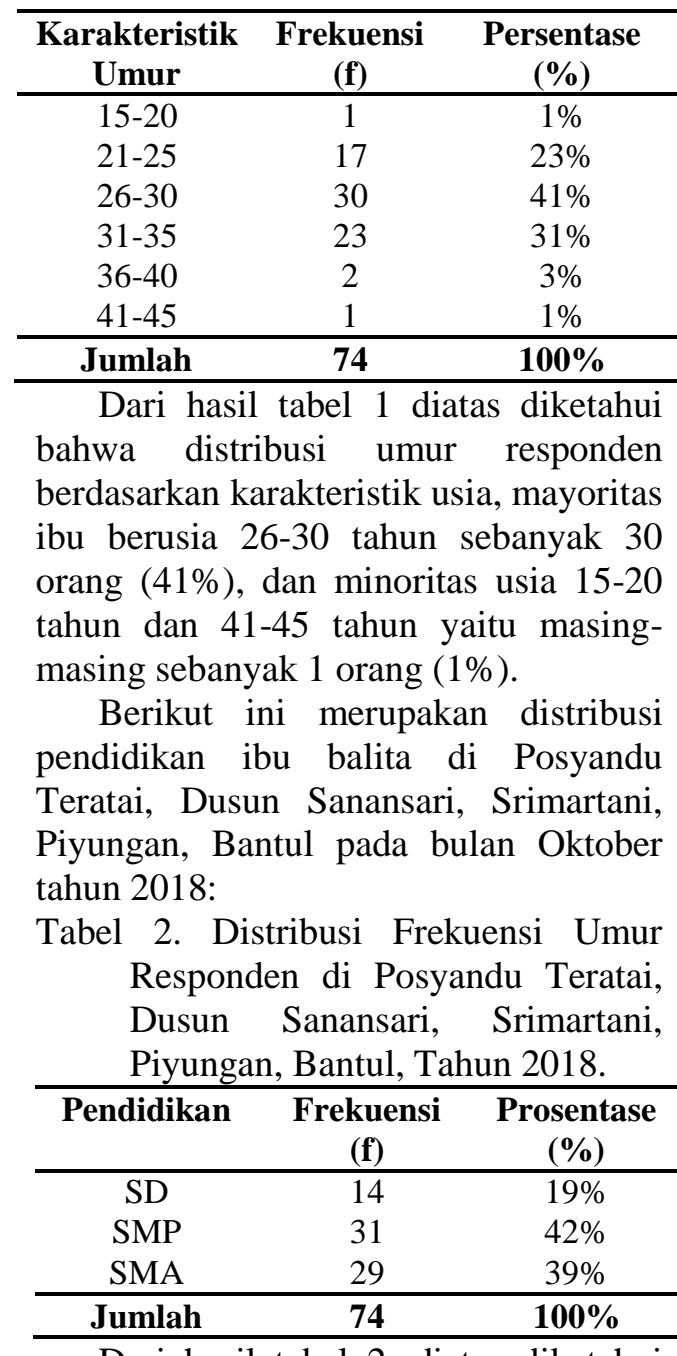

Dari hasil tabel 2. diatas diketahui bahwa distribusi pendidikan, mayoritas pendidikan responden adalah Sekolah Menengah Pertama (SMP) dengan jumlah 31 responden (42\%) dan minoritas pendidikan responden adalah Sekolah Dasar (SD) dengan jumlah 14 responden (19\%).
Berikut ini merupakan distribusi pekerjaan ibu balita di Posyandu Teratai, Dusun Sanansari, Srimartani, Piyungan, Bantul pada bulan Oktober Tahun 2018:

Tabel 3. Distribusi Frekuensi Umur

Responden di Posyandu Teratai,

Dusun Sanansari, Srimartani, Piyungan, Bantul, Tahun 2018.

\begin{tabular}{lcc}
\hline Pekerjaan & $\begin{array}{c}\text { Frekuensi } \\
(\mathbf{f})\end{array}$ & $\begin{array}{c}\text { Prosentase } \\
(\%)\end{array}$ \\
\hline S Swasta & 1 & $1 \%$ \\
P Pedagang & 3 & $4 \%$ \\
B Buruh & 9 & $12 \%$ \\
I Ibu & 61 & $83 \%$ \\
Rumah & & \\
Tangga & & \\
Jumlah & 74 & $100 \%$ \\
\hline
\end{tabular}

Dari hasil tabel 3 diatas diketahui bahwa distribusi pekerjaan responden mayoritas adalah ibu rumah tangga dengan jumlah 61 orang (83\%) dan minoritas pekerjaan responden adalah swasta dengan responden 1 orang (1\%).

Berikut ini merupakan distribusi pengetahuan ibu tentang Kadarzi di Posyandu Teratai, Dusun Sanansari, Srimartani, Piyungan, Bantul pada bulan Oktober tahun 2018:

Tabel 4. Distribusi frekuensi Pengetahuan Ibu Tentang Kadarzi di Posyandu Teratai Dusun Sanansari, Srimartani, Piyungan, Bantul, Tahun 2018.

\begin{tabular}{lcc}
\hline Pengetahuan & $\begin{array}{c}\text { Frekuensi } \\
\text { (f) }\end{array}$ & $\begin{array}{c}\text { Prosentase } \\
(\boldsymbol{\%})\end{array}$ \\
\hline Baik & 44 & 59 \\
Tidak Baik & 30 & 41 \\
\hline Jumlah & $\mathbf{7 4}$ & $\mathbf{1 0 0}$ \\
\hline
\end{tabular}

Tabel 4. menunjukkan bahwa dari 74 responden sebagian besar responden berpengetahuan baik yaitu sebanyak 44 orang (59\%) dan responden berpengetahuan tidak baik yaitu sebanyak 30 orang (41\%).

Berikut ini merupakan distribusi perilaku ibu tentang Kadarzi di Posyandu Teratai, Dusun Sanansari, Srimartani, Piyungan, Bantul pada bulan Oktober tahun 2018: 


\section{Jurnal Delima Harapan 2020}

Tabel 5. Distribusi frekuensi Perilaku Ibu Tentang Kadarzi di Posyandu Teratai Dusun Sanansari, Srimartani, Piyungan, Bantul, Tahun 2018.

\begin{tabular}{lcc}
\hline Perilaku & $\begin{array}{c}\text { Frekuensi } \\
\text { (f) }\end{array}$ & $\begin{array}{c}\text { Prosentase } \\
(\boldsymbol{\%})\end{array}$ \\
\hline Baik & 42 & 57 \\
Tidak Baik & 32 & 43 \\
\hline Jumlah & $\mathbf{7 4}$ & $\mathbf{1 0 0}$ \\
\hline
\end{tabular}

Tabel 5. menunjukkan bahwa dari 74 responden sebagian besar memiliki perilaku Kadarzi baik yaitu sebanyak 42 orang (57\%) dan responden yang memiliki perilaku Kadarzi tidak baik sebanyak 32 orang (43\%).

Berikut ini merupakan distribusi status gizi balita di Posyandu Teratai, Dusun Sanansari, Srimartani, Piyungan, Bantul pada bulan Oktober tahun 2018: Tabel 6. Distribusi frekuensi Status Gizi

Anak Balita di Posyandu Teratai Dusun Sanansari, Srimartani, Piyungan, Bantul, Tahun 2018.

\begin{tabular}{lcc}
\hline Status Gizi & $\begin{array}{c}\text { Frekuensi } \\
(\mathbf{f})\end{array}$ & $\begin{array}{c}\text { Prosentase } \\
(\boldsymbol{\%})\end{array}$ \\
\hline Gemuk & 0 & 0 \\
Normal & 68 & 92 \\
Kurus & 5 & 7 \\
Sangat Kurus & 1 & 1 \\
\hline Jumlah & $\mathbf{7 4}$ & $\mathbf{1 0 0}$ \\
\hline \multicolumn{1}{c}{ Tabel 6. }
\end{tabular}

74 balita dalam penelitian ini sebagian besar memiliki status gizi normal yaitu sebanyak 68 balita (92\%), 5 balita (7\%) dengan status gizi kurus dan 1 balita (1\%) dengan status gizi sangat kurus.

Berikut ini adalah tabulasi silang pengetahuan dengan status gizi anak balita:

Tabel 7. Tabulasi Silang Pengetahuan Ibu dengan Status Gizi Anak Balita di Posyandu Teratai Dusun Sanansari, Srimartani, Piyungan, Bantul Tahun 2018.

\begin{tabular}{|c|c|c|c|c|c|c|c|c|}
\hline \multirow{3}{*}{ Pengetahuan } & \multicolumn{6}{|c|}{ Status gizi } & \multirow{2}{*}{\multicolumn{2}{|c|}{ Total }} \\
\hline & \multicolumn{2}{|c|}{ Normal } & \multicolumn{2}{|c|}{ Kurus } & \multicolumn{2}{|c|}{$\begin{array}{l}\text { Sangat } \\
\text { kurus }\end{array}$} & & \\
\hline & $\mathrm{F}$ & $\%$ & $\mathrm{~F}$ & $\%$ & $\mathrm{~F}$ & $\%$ & $\mathrm{~F}$ & $\%$ \\
\hline Baik & 43 & 58,1 & 0 & 0 & 1 & 1,4 & 44 & 59,5 \\
\hline Tidak baik & 25 & 33,8 & 5 & 6,8 & 0 & 0 & 30 & 40,5 \\
\hline Total & 68 & 91,9 & 5 & 6,8 & 1 & 1,4 & 74 & 100 \\
\hline
\end{tabular}

Berdasarkan tabulasi silang antara pengetahuan ibu dengan status gizi pada balita , diketahui bahwa mayoritas responden memiliki pengetahuan pada kategori baik dengan status gizi pada kategori normal sebanyak 43 responden $(58,1 \%)$.

Untuk menguji hubungan antara pengetahuan ibu tentang Kadarzi dengan status gizi anak balita di Posyandu Teratai, Dusun Sanansari, Srimartani, Piyungan, Bantul tahun 2018 dilakukan analisa dengan program SPSS versi 16.0 dengan rumus Chi Square, adapun hasilnya sebagai berikut:

Tabel 8. Hasil Analisis Chi Square Hubungan antara Pengetahuan dengan Status Gizi Anak Balita di Posyandu Teratai Dusun Sanansari, Srimartani, Piyungan, Bantul, Tahun 2018.

\begin{tabular}{lccc}
\hline & Value & df & $\begin{array}{l}\text { Asymp. } \\
\text { Sig. (2- } \\
\text { sided) }\end{array}$ \\
\hline $\begin{array}{l}\text { Pearson Chi- } \\
\text { Square }\end{array}$ & 8.417 & 2 & .015 \\
$\begin{array}{l}\text { Likelihood } \\
\text { Ratio }\end{array}$ & 10.475 & 2 & .005 \\
$\begin{array}{l}\text { Linear-by- } \\
\text { Linear } \\
\text { Association } \\
\text { N of Valid } \\
\text { Cases }\end{array}$ & 2.295 & 1 & .013 \\
\hline
\end{tabular}

Berdasarkan tabel 8. menunjukkan bahwa terdapat hubungan yang signifikan antara pengetahuan ibu dengan status gizi pada balita di Posyandu Teratai, Dusun Sanansari, Srimartani, Piyungan, Bantul, tahun 2018 yang ditunjukkan dengan nilai $C h i$ Square sebesar 8.417, sig 0,015 $(p<0,05)$, sehingga dapat diartikan bahwa apabila pengetahuan yang dimiliki semakin tinggi maka status gizi balita akan semakin baik, begitu pula sebaliknya apabila pengetahuan yang dimiliki rendah maka status gizi balita juga kurang. Hal ini diperkuat dengan hasil tabulasi silang yang menunjukkan bahwa sebagian besar responden memiliki pengetahuan baik dengan status gizi pada kategori normal sebanyak 43 responden $(58,1 \%)$, sehingga dapat disimpulkan bahwa pengetahuan yang dimiliki oleh 


\section{Jurnal Delima Harapan 2020}

responden mempengaruhi status gizi pada balita khususnya balita di Posyandu Teratai, Dusun Sanansari, Srimartani, Piyungan, Bantul tahun 2018.

Hasil diatas mendukung Notoatmodjo (2011) yang menyatakan bahwa pengetahuan tentang gizi dan makanan, yang harus dikonsumsi agar tetap sehat, merupakan faktor penentu kesehatan seseorang. Pengetahuan tentang gizi yang harus dimiliki masyarakat antara lain kebutuhankebutuhan zat gizi bagi tubuh (karbohidrat, protein, lemak, vitamin, dan mineral). Selain itu, jenis makanan sehari-hari yang mengandung zat-zat gizi yang dibutuhkan tubuh tersebut, baik secara kualitas maupun kuantitas, akibat atau penyakit-penyakit yang disebabkan karena kekurangan gizi dan sebagainya.

Berikut ini adalah tabulasi silang pengetahuan dengan status gizi anak balita:

Tabel 9. Tabulasi Silang Perilaku Ibu dengan Status Gizi Anak Balita di Posyandu Teratai Dusun Sanansari, Srimartani, Piyungan, Bantul Tahun 2018.

\begin{tabular}{|c|c|c|c|c|c|c|c|}
\hline \multirow{3}{*}{ Perilaku } & \multicolumn{5}{|c|}{ Status gizi } & \multirow{2}{*}{\multicolumn{2}{|c|}{ Total }} \\
\hline & \multicolumn{2}{|c|}{ Normal } & \multicolumn{2}{|c|}{ Kurus } & $\begin{array}{l}\text { Sangat } \\
\text { kurus }\end{array}$ & & \\
\hline & $\mathrm{F}$ & $\%$ & $\mathrm{~F}$ & $\%$ & $\mathrm{~F} \%$ & $\mathrm{~F}$ & $\%$ \\
\hline Baik & 43 & $\begin{array}{l}58, \\
1\end{array}$ & 0 & 0 & $1 \quad 1,4$ & 44 & 59,5 \\
\hline $\begin{array}{l}\text { Tidak } \\
\text { baik }\end{array}$ & 25 & $\begin{array}{l}33 \\
8\end{array}$ & 5 & 6,8 & $\begin{array}{ll}0 & 0\end{array}$ & 30 & 40,5 \\
\hline Total & 68 & 91,9 & 5 & 6,8 & $\begin{array}{ll}1 & 1,4\end{array}$ & 74 & 100 \\
\hline
\end{tabular}

Berdasarkan tabulasi silang antara perilaku ibu dengan status gizi anak balita diketahui bahwa mayoritas responden memiliki perilaku pada kategori baik dengan status gizi pada kategori baik sebanyak 41 responden $(55,4 \%)$.

Hubungan antara perilaku ibu dengan status gizi anak balita di Posyandu Teratai, Dusun Sanansari, Srimartani, Piyungan, Bantul tahun 2018 dianalisa dengan program SPSS versi 16.0 .
Tabel 10. Hasil Analisis Chi Square Hubungan Antara Perilaku dengan Status Gizi Anak Balita di Posyandu Teratai Dusun Sanansari, Srimartani, Piyungan, Bantul, Tahun 2018.

\begin{tabular}{lccc}
\hline & Value & df & $\begin{array}{l}\text { Asymp. } \\
\text { Sig. (2- } \\
\text { sided) }\end{array}$ \\
\hline $\begin{array}{l}\text { Pearson Chi- } \\
\text { Square }\end{array}$ & 7.671 & 2 & .022 \\
$\begin{array}{l}\text { Likelihood } \\
\text { Ratio }\end{array}$ & 9.865 & 2 & .007 \\
$\begin{array}{l}\text { Linear-by- } \\
\text { Linear } \\
\text { Association } \\
\text { N of Valid } \\
\text { Cases }\end{array}$ & 1.876 & 1 & .171 \\
\hline
\end{tabular}

Berdasarkan tabel 10. menunjukkan bahwa terdapat hubungan yang signifikan antara perilaku ibu dengan status gizi pada balita di Posyandu Teratai, Dusun Sanansari, Srimartani, Piyungan, Bantul, tahun 2018 yang ditunjukkan dengan nilai Chi Square sebesar 7.671, sig 0,022 $(p<0,05)$, sehingga dapat diartikan bahwa perilaku seseorang didukung oleh pendidikan responden dan juga informasi yang didapatkan oleh responden dari petugas kesehatan dan juga program Pemerintah Daerah mengenai pelaksanaan Kadarzi.

Hal ini diperkuat dengan hasil tabulasi silang yang menunjukkan bahwa sebagian besar responden memiliki perilaku baik dengan status gizi pada kategori normal sebanyak 41 responden $(55,4 \%)$, sehingga dapat disimpulkan bahwa perilaku yang dimiliki oleh responden mempengaruhi status gizi pada balita khususnya balita di Posyandu Teratai, Dusun Sanansari, Srimartani, Piyungan, Bantul tahun 2018.

Hasil diatas mendukung Departemen Kesehatan RI (2007) yang menyatakan bahwa perilaku gizi seimbang yaitu pengetahuan, sikap dan praktek keluarga yang mampu mengkonsumsi makanan yang mengandung semua zat gizi yang dibutuhkan, dalam jumlah yang sesuai 


\section{Jurnal Delima Harapan 2020}

dengan kebutuhan setiap individu dalam keluarga dan bebas dari pencemaran.

Selain itu menurut H.L. Blum menyatakan bahwa perilaku merupakan faktor kedua yang mempengaruhi derajat kesehatan masyarakat karena sehat atau tidak sehatnya lingkungan kesehatan individu, keluarga dan masyarakat sangat tergantung pada perilaku manusia itu sendiri.

Di samping itu, juga dipengaruhi oleh kebiasaan, adat istiadat, kebiasaan, kepercayaan, pendidikan sosial ekonomi, dan perilaku-perilaku lain yang melekat pada dirinya.

\section{KESIMPULAN}

Berdasarkan hasil penelitian dan pembahasan seperti yang sudah dipaparkan pada bab sebelumnya, maka dari penelitian ini dapat ditarik beberapa kesimpulan sebagai berikut:

Pengetahuan ibu tentang Kadarzi di Posyandu Teratai Dusun Sanansari, Srimartani, Piyungan, Bantul sebagian besar dalam kategori baik yaitu sebanyak 44 orang (59\%).

Perilaku ibu tentang kadarzi di Posyandu Teratai Dusun Sanansari, Srimartani, Piyungan, Bantul sebagian besar dalam kategori baik yaitu sebanyak 42 orang (57\%).

Status gizi anak balita di Posyandu Teratai Dusun Sanansari, Srimartani, Piyungan, Bantul sebagian besar dalam kategori baik yaitu sebanyak 68 balita (92\%).

Hasil korelasi Chi Square $\left(x^{2}\right)$ pada hubungan pengetahuan ibu tentang Kadarzi dengan status gizi anak balita diperoleh $p<0,05$, yang berarti ada hubungan yang signifikan antara pengetahuan ibu dengan status gizi balita. Begitu pula pada korelasi antara perilaku ibu tentang Kadarzi dengan status gizi balita diperoleh nilai $p<$ 0,05 , yang berarti ada hubungan yang signifikan antara perilaku ibu tentang Kadarzi dengan status gizi anak balita.

\section{REFERENSI}

A. Wawan dan Dewi M. 2010. Teori \& Pengukuran Pengetahuan, Sikap, Dan Perilaku Manusia. Yogyakarta: Nuha Medika.

Aditianti,Sri Prihatini, dan Hermina. 2016. Buletin Penelitian Kesehatan. Vol. 44 No. 2. Pengetahuan, Sikap dan Perilaku Individu Tentang Makanan Beraneka Ragam Sebagai Salah Satu Indikator Keluarga Sadar Gizi (KADARZI).

Departemen Kesehatan RI. 2007. Pedoman Strategi KIE Keluarga Sadar Gizi (Kadarzi). Direktorat Jenderal Bina Kesehatan Masyarakat, Direktorat. Bina Gizi Masyarakat.

Dinas Kesehatan D.I.Yogyakarta. 2017. Profil Kesehatan D.I Yogyakarta Tahun 2017. Yogyakarta: Dinas Kesehatan D.I. Yogyakarta.

Dinas Kesehatan Bantul 2017. Profil Kesehatan Kabupaten Bantul Tahun 2017. Bantul: Dinas Kesehatan Bantul.

Ema Anggraeni. 2015. Jurnal Kebidanan. Hubungan Pengetahuan Ibu tentang Keluarga Sadar Gizi(Kadarzi) dengan Perilaku Sadar Gizi Pada Ibu Balita Di Posyandu Anggrek Kaligayam Kulur Temon Kulonprogo.

Handoko Riwidikdo. 2012. Statistik Kesehatan. Yogyakarta: Nuha Medika.

Hanum Marimbi. 2010. Tumbuh Kembang, Status Gizi, dan Imunisasi Dasar Pada Balita. Yogyakarta: Nuha Medika.

Hardinsyah dan I Dewa Nyoman Supariasa. 2016. Ilmu Gizi Teori \& Aplikasi. Jakarta: Buku Kedokteran EGC.

http://gizi.depkes.go.id/wpcontent/uploads/2011/11/buku-skantropometri-2010.pdf di akses pada tanggal 30 November 2018.

Kemenkes RI. 2014. Pedoman Pelayanan Gizi Puskesmas. Direktorat Jenderal Bina Gizi dan KIA.Jakarta. 


\section{Jurnal Delima Harapan 2020}

Lapau, Buchori. 2013. Metode Penelitian Kesehatan. Yogyakarta: Yayasan Obor Indonesia.

Mega Andini dan Anita Dewi L. 2015. Jurnal Kebidanan. Hubungan Pengetahuan Ibu Balita Usia 2-5 Tahun Tentang Keluarga Sadar Gizi Dengan Status Gizi Balita Di Posyandu Mandiri Tawangsari RW 34 Mojosongo Jebres Surakarta Tahun 2015.

Notoatmodjo. 2011. Ilmu Perilaku Kesehatan. Jakarta: Rineka Cipta.

Notoatmodjo. 2012. Metodologi Penelitian Kesehatan. Jakarta: Rineka Cipta.

Dian S. Pramukti dan Sri Sularsih Endartiwi. 2017. Ilmu Gizi. Yogyakarta: Mitra.

Priyoto. 2014. Teori Sikap Dan Perilaku dalam Kesehatan. Yogyakarta : Nuha Medika.

Riskesdas. 2018. Hasil Pemantauan Status Gizi (PSG) Tahun 2017. Jakarta: Kementrian Kesehatan.

Riyanto, Agus. 2011. Pengolahan dan Analisis Data Kesehatan. Yogyakarta: Nuha Medika.

Santoso, Singgih. 2012. Statistik Parametrik. Jakarta: Elex Media Komputindo.

Sugiyono. 2016. Metode Penelitian Kombinasi (Mixed Methods). Bandung: Alfabeta.

Sugiyono. 2015. Statistika Untuk Penelitian. Bandung: Alfabeta.

Titik Lestari, 2015. Kumpulan Teori Untuk Kajian Pustaka Penelitian Kesehatan. Yogyakarta: Nuha Medika.

Verena Meirike Arbella, Erna Widyastuti, Sri Rahayu. 2013. Jurnal Kebidanan.Vol. 2 No. 5. Hubungan Pengetahuan dan Sikap Ibu Tentang Keluarga Sadar Gizi Dengan Perilaku Sadar Gizi Keluarga Balita Di Desa Karangsono Kecamatan Kwadungan Kabupaten Ngawi Tahun 2013.

World Health Organization (WHO). 2017. Global Nutrition Review 2016-2017 [serial online].
Tersedia dari http://www.who.int/nutrition/topic s/global-nutrition-policy-review2016// (Diakses pada tanggal 4 September 2018). 